\title{
Effect of Nutrient Deficiencies on Growth and Leaf Tissue Concentration of Gerbera var. Savannah
}

\author{
Ch. Sai Ratna Sharavani*, B. Neeraja Prabhakar, M. Chandini Patnaik and A. Girwani \\ College of Horticulture, Rajendaranagar-500030 \\ Sri Konda Laxman Telangana State Horticultural University, Hyderabad, Telangana, India \\ *Corresponding author
}

\section{A B S T R A C T}

Keywords

Gerbera, Hoagland solutions, Solution culture, Nutrient content, Growth

Article Info

Accepted:

15 July 2018

Available Online:

10 August 2018
Present investigation was conducted in AICRIP on Flower crops, Rajendranagar, Rangareddy district of Telangana state to study the influence of different nutrient deficiencies on growth and leaf tissue concentrations of Gerbera var. Savannah through solution culture. Plants were treated with complete Hoagland solution and deficiencies were incorporated with a complete nutrient formula minus one of the nutrients. Plants treated with nitrogen deficiency solution showed significant reduction in growth followed by $\mathrm{P}, \mathrm{K}, \mathrm{Ca}, \mathrm{Fe}$, and $\mathrm{Mg}$. Root length of phosphorous deficient plants and shoot/root ratio of iron deficient plants were increased. Visual deficiency symptoms were expressed except for manganese deficiency during the period of study (60 DAT). Leaf analysis at 60 DAT revealed that in deficiency situation, content of individual mineral element was significantly reduced.

\section{Introduction}

Gerbera (Gerbera jamesonii L.) belonging to Asteraceace is one among the top ten cut flowers in the world, indigenous to South Africa and Asia as a perennial herb. In India, they are distributed in the temperate Himalayas from Kashmir to Nepal at altitudes from 1,300 to $3,200 \mathrm{~m}$. among cut flowers as per Global trends in floriculture, it occupies fourth place (Sujatha et al., 2002). In India, it is cultivated in an area of 900 ha with a production of 4000 MT loose flowers and 23.84 lakhs cut flowers with Assam as state under highest area of cultivation (600 ha) and Telangana being the major cut flower producer (6.01 lakhs) (Anon., 2014-15). In Telangana it is cultivated in an area of 70 ha under Naturally ventilated polyhouses.

Gerberas, for commercial production, are considered as moderate feeders. This moderate level of fertility produces a plant with a proportional leaf area to flower ratio. Any raise or decrease in nutrient supply results in unusual growth and yield loss thereby stressing the need of balanced nutrition. Information on deficiency symptoms of 
nutrients would aid the grower in problem identification. Qualitative techniques, as visual diagnosis are very useful to detect an individual problem, but when visual symptom shows up, some reduction in yield has already been caused. For this reason quantitative technique such as foliar analysis is preferred. The critical leaf tissue concentration also highly significant to determine nutritional status of plants. Balancing the needs of plant and periodic monitoring will help in assured implementation of nutritional requirements. Therefore, the standards for leaf tissue nutrient concentrations are important to determine nutritional status of plants and take up corrective measures. Hence this experiment is aimed to elucidate the influence of different nutrient deficiencies on growth and leaf tissue concentrations of Gerbera.

\section{Materials and Methods}

Tissue culture plants of Gerbera variety Savannah grown prior to treatment in peat based compost were used in the present investigation. Plants of uniform size with 3-4 leaf stage were selected. Twelve treatments (Fig. 1) viz. Complete Hoagland solution and complete minus $\mathrm{N}, \mathrm{P}, \mathrm{K}, \mathrm{Ca}, \mathrm{Mg}, \mathrm{S}, \mathrm{Mn}, \mathrm{B}$, $\mathrm{Fe}, \mathrm{Zn}, \mathrm{Cu}$ were used to incorporate deficiencies (Table 1) (Hoagland and Arnon, 10). The nutrient treatments were arranged in a completely randomized design with 12 plants each treatment and daily provided aeration using Aspirator (Fig. 2). Nutrient solutions were replaced at weekly intervals and volume is maintained by adding distilled water. Observations regarding leaf area, root length and shoot/root ratio were recorded at end of the experiment i.e., 60 DAT. Leaves were collected at end of the experiment and analyzed for content of Nitrogen by employing KELPLUS digestion and distillation system (Subbaiah and Asija, 1956), Phosphorous by Vanado-molybdo phosphoric yellow colour method (Jackson, 1973), Potassium by Flame photometer (Tandon,
1993), Calcium and Magnesium by Versenate titration method (Tandon, 1993), Sulphur by Turbidity method (Chesnin and Yien, 1950), Boron by hot water extraction method (Berger and Troug, 1939), Mn, Zn, Fe, Cu by feeding extract to atomic absorption spectrophotometer (Tandon, 1993). The data was analyzed by using software OPSTAT in CRD.

\section{Results and Discussion}

\section{Deficiency of macronutrients}

\section{Nitrogen}

Leaf tissue $\mathrm{N}$ concentration of Gerbera plants treated with complete nutrient solution was recorded 3.12 per cent, whereas for plants treated with $\mathrm{N}$ deficient nutrient solution has recorded 1.1 per cent (Table 2). For pot gerbera, leaf tissue $\mathrm{N}$ concentration was reported to be 2.7-4.1 per cent (Dole and Wilkins, 2005) and in cut gerbera was 1.5-3.5 per cent, under $\mathrm{N}$ deficiency conditions, threshold level of $\mathrm{N}$ in cut Gerbera was reported to be 1.2 per cent (Ocampo, 2001). There was significant reduction in the growth as compared to complete treatment (control) (Table 3). Decrease in values was recorded for plant height $(11.40 \mathrm{~cm}, 25.50 \mathrm{~cm})$, leaf area $\left(20.87 \mathrm{~cm}^{2}, 44.34 \mathrm{~cm}^{2}\right)$, root length $(13.65 \mathrm{~cm}$, $28.97 \mathrm{~cm}$ ) and shoot/root ratio $(2.12,2.88)$. Since $\mathrm{N}$ is fourth most major element required for plant growth and development it's deficiency resulted in poor growth. Sulphur content was recorded higher $(0.67 \%)$ in $\mathrm{N}$ deficient leaves (Table 2) due to antagonism between $\mathrm{N}$ and $\mathrm{S}$ which has resulted in accumulation of more non-protein $S$ compounds in vegetative tissues (Fageria, 2001).

\section{Phosphorous}

Leaf tissue $\mathrm{P}$ concentration of Gerbera plants treated with complete nutrient solution was recorded 0.6 per cent, whereas for plants 
treated with $\mathrm{P}$ deficient nutrient solution has recorded 0.11 percent (Table 2). For pot gerbera, leaf tissue $\mathrm{P}$ concentration was reported to be 0.3-0.7 per cent (Dole and Wilkins, 2005) and in cut gerbera was 0.2-0.5 per cent, under $\mathrm{P}$ deficiency conditions, threshold level of $\mathrm{P}$ in cut Gerbera was reported to be 0.15 per cent (Ocampo, 2001). There was significant reduction in the growth as compared to control treatment (Table 3). Decrease in values was recorded for plant height $(14.50 \mathrm{~cm}, 25.50 \mathrm{~cm})$ and leaf area $\left(22.23 \mathrm{~cm}^{2}, 44.34 \mathrm{~cm}^{2}\right)$. Whereas, root length $(33.20 \mathrm{~cm}, 28.97 \mathrm{~cm})$ and shoot/root ratio $(3.12,2.88)$ was recorded higher for $\mathrm{P}$ deficient treatment compared to complete nutrient treatment. The increase in shoot/root ratio in phosphorous deficient plants was due to increase in root length due to elongation of tap root because of diversion of assimilates from shoot to root in search of phosphorous (Fredeen et al., 1989).

\section{Potassium}

Leaf tissue $\mathrm{K}$ concentration of Gerbera plants treated with complete nutrient solution was recorded 2.97 per cent, whereas for plants treated with $\mathrm{K}$ deficient nutrient solution has recorded 1.46 percent (Table 2). For pot gerbera leaf tissue $\mathrm{K}$ concentration was reported to be 3.1-3.9 per cent (Dole and Wilkins, 2005) and in cut gerbera was 2.5-4.5 per cent, under $\mathrm{K}$ deficiency conditions, threshold level of $\mathrm{K}$ in cut Gerbera was reported to be 2 per cent (Ocampo, 2001). There was significant reduction in the growth as compared to control treatment except for shoot/root ratio which was recorded higher $(3.45,2.88)$ (Table 3). Decrease in values was recorded for plant height $(16.40 \mathrm{~cm}, 25.50$ $\mathrm{cm})$, leaf area $\left(28.45 \mathrm{~cm}^{2}, 44.34 \mathrm{~cm}^{2}\right)$ and root length $(22.84,28.97)$. There was an interaction recorded between $\mathrm{K}, \mathrm{N}$ and $\mathrm{K}, \mathrm{Mg}$ due to antagonism between them which resulted in increase in $\mathrm{N}$ and $\mathrm{Mg}$ content $(3.45 \%$ and
$0.79 \%$ ) (Table 2). The increase in $\mathrm{N}$ was due to the competition of $\mathrm{K}$ with $\mathrm{N}\left(\mathrm{NH}_{4}\right)$ for uptake (Chang et al., 2001). Both $\mathrm{Mg}$ and $\mathrm{K}$ ions are quite similar in size and charge and hence, exchange site cannot distinguish the difference between the ions (Ujwala, 2011), thereby there was increase in $\mathrm{Mg}$ content in $\mathrm{K}$ deficient leaves.

\section{Calcium}

Leaf tissue $\mathrm{Ca}$ concentration for Gerbera plants treated with complete nutrient solution was recorded 1.43 per cent, whereas for plants treated with $\mathrm{Ca}$ deficient nutrient solution has recorded 0.33 percent (Table 2). For pot gerbera leaf tissue $\mathrm{Ca}$ concentration was reported to be 3.1-3.9 per cent (Dole and Wilkins, 2005) and in cut gerbera was 1.0-3.5 per cent, under $\mathrm{Ca}$ deficiency conditions, threshold level of $\mathrm{Ca}$ in cut Gerbera was reported to be 0.7 per cent (Ocampo, 2001). There was significant reduction in the growth as compared to control (Table 3). Decrease in values was recorded for plant height (15.63 $\mathrm{cm}, 25.50 \mathrm{~cm})$, leaf area $\left(25.55 \mathrm{~cm}^{2}, 44.34\right.$ $\left.\mathrm{cm}^{2}\right)$, root length $(19.38 \mathrm{~cm}, 28.97 \mathrm{~cm})$ and shoot/root ratio $(2.75,2.88)$. Boron concentration was recorded higher (71.75 ppm) in Ca deficient leaves (Table 2) due to antagonism between $\mathrm{Ca}$ and $\mathrm{B}$ due to localization of $\mathrm{Ca}$ in cell wall which had decreased cell wall boron permeability (Turan et al., 2009).

\section{Magnesium}

Leaf tissue $\mathrm{Mg}$ concentration for Gerbera plants treated with complete nutrient solution was recorded 0.6 per cent, whereas for plants treated with $\mathrm{Mg}$ deficient nutrient solution has recorded 0.13 percent (Table 2). For pot gerbera leaf tissue $\mathrm{Mg}$ concentration was reported to be $0.24-0.63$ per cent and in cut gerbera was 0.2-0.7 per cent, under $\mathrm{Mg}$ deficiency conditions, threshold level of $\mathrm{Mg}$ in 
cut Gerbera was reported to be 0.15 per cent (Ocampo, 2001). There was significant reduction in the growth as compared to control treatment except for shoot/root ratio (3.26, 2.88) which recorded higher (Table 3). Decrease in values was recorded for plant height $(17.87 \mathrm{~cm}, 25.50 \mathrm{~cm})$, leaf area $\left(31.78 \mathrm{~cm}^{2}, 44.34 \mathrm{~cm}^{2}\right)$ and root length $(19.75$ $\mathrm{cm}, 28.97 \mathrm{~cm})$.

There was an antagonistic interaction recorded among $\mathrm{Mg}$ and $\mathrm{K}, \mathrm{Ca}, \mathrm{Mn}$ which resulted in increased concentrations of $\mathrm{K}(3.51 \%), \mathrm{Ca}$ (2.09 \%) and Mn (109.45 ppm) in leaves (Table 2). Both $\mathrm{Mg}$ and $\mathrm{K}$ ions are quite similar in size and charge and hence, exchange site cannot distinguish the difference between the ions and binding site of $\mathrm{K}$ is much stronger than $\mathrm{Mg}$ and it easily out-compete $\mathrm{Mg}$ i.e., more $\mathrm{K}$ was absorbed at exchange sites (Ujwala, 2011). High rhizosphere concentrations of calcium, relative to magnesium are inhibitory to the absorption of magnesium and vice versa (Merhaut, 2006). Manganese, as a divalent cation, can compete with magnesium for binding sites on soil particles as well as biological membranes within plants (Merhaut, 2006).

\section{Sulphur}

Leaf tissue $\mathrm{S}$ concentration for Gerbera plants treated with complete nutrient solution was recorded 0.38 per cent, whereas for plants treated with $\mathrm{S}$ deficient nutrient solution has recorded 0.08 per cent (Table 2).

For cut gerbera leaf tissue $\mathrm{S}$ concentration was 0.25-0.5 per cent and under $S$ deficiency conditions, threshold level of $\mathrm{S}$ in cut Gerbera was reported to be 0.16 per cent (Ocampo, 2001). There was significant reduction in the growth as compared to control treatment except for shoot/root ratio $(2.98,2.88)$ which recorded higher (Table 3). Decrease in values was recorded for plant height $(18.77 \mathrm{~cm}, 25.50$ $\mathrm{cm})$, leaf area $\left(32.38 \mathrm{~cm}^{2}, 44.34 \mathrm{~cm}^{2}\right)$ and root length $(19.58 \mathrm{~cm}, 28.97 \mathrm{~cm})$.

\section{Deficiency of Micronutrients}

\section{Manganese}

Leaf tissue $\mathrm{Mn}$ concentration for Gerbera plants treated with complete nutrient solution was recorded $72.93 \mathrm{ppm}$, whereas for plants treated with Mn deficient nutrient solution has recorded $28.4 \mathrm{ppm}$ (Table 2). For pot gerbera leaf tissue $\mathrm{Mn}$ concentration was reported to be 30-260 ppm (Dole and Wilkins, 2005) and in cut gerbera was 40-250 ppm, under Mn deficiency conditions, threshold level of $\mathrm{Mn}$ in cut Gerbera was reported to be $30 \mathrm{ppm}$ (Ocampo, 2001). There was significant reduction in the growth as compared to control treatment (Table 3).

Decrease in values was recorded for plant height $(22.15 \mathrm{~cm}, 25.50 \mathrm{~cm})$, leaf area $(37.78$ $\left.\mathrm{cm}^{2}, 44.34 \mathrm{~cm}^{2}\right)$, root length $(26.41 \mathrm{~cm}, 27.93$ $\mathrm{cm})$ and shoot/root ratio $(2.66,2.88)$.

\section{Boron}

Leaf tissue B concentration for Gerbera plants treated with complete nutrient solution was recorded $44.50 \mathrm{ppm}$, whereas for plants treated with $\mathrm{B}$ deficient nutrient solution has recorded 14.6 ppm (Table 2). For pot gerbera leaf tissue B concentration was reported to be 19-50 ppm (Dole and Wilkins, 2005) and in cut gerbera was 20-60 ppm, under B deficiency conditions, threshold level of $\mathrm{B}$ in cut Gerbera was reported to be $15 \mathrm{ppm}$ (Ocampo, 2001). There was significant reduction in the growth as compared to control treatment (Table 3).

Decrease in values was recorded for plant height $(20.55 \mathrm{~cm}, 23.50 \mathrm{~cm})$, leaf area $(33.57$ $\left.\mathrm{cm}^{2}, 42.34 \mathrm{~cm}^{2}\right)$, root length $(25.85 \mathrm{~cm}, 27.93$ $\mathrm{cm})$ and shoot/root ratio $(2.76,2.88)$. 


\section{Iron}

Leaf tissue $\mathrm{Fe}$ concentration for Gerbera plants treated with complete nutrient solution was recorded $169.55 \mathrm{ppm}$, whereas for plants treated with Fe deficient nutrient solution has recorded $14.6 \mathrm{ppm}$ (Table 2). For pot gerbera leaf tissue Fe concentration was reported to be 60-130 ppm (Dole and Wilkins, 2005) and in cut gerbera was 50-200 ppm, under $\mathrm{Fe}$ deficiency conditions, threshold level of Fe in cut Gerbera was reported to be $40 \mathrm{ppm}$ (Ocampo, 2001). There was significant reduction in the growth as compared to control treatment except for shoot/root ratio which recorded higher $(3.11,2.88)$ (Table 2). Decrease in values was recorded for plant height $(13.41 \mathrm{~cm}, 25.50 \mathrm{~cm})$, leaf area $(33.60$ $\left.\mathrm{cm}^{2}, 44.34 \mathrm{~cm}^{2}\right)$ and root length $(16.40 \mathrm{~cm}$, $28.97 \mathrm{~cm}$ ).

There was an interaction recorded between Fe, $\mathrm{Cu}$ and $\mathrm{Fe}, \mathrm{Zn}$ due to antagonism between them which resulted in increase in $\mathrm{Cu}$ and $\mathrm{Zn}$ content (28.5 ppm and $79.25 \mathrm{ppm}$ ) (Table 2). $\mathrm{Cu}$ and $\mathrm{Fe}$ have similar affinity to different enzymatic systems (Cohu and Pilon, 2007). Hence, under Fe deficiency, a metabolic shift had occurred which had enhanced the reduction capacity resulting in a greater uptake of $\mathrm{Cu}$ (Gama et al., 2015), whereas, $\mathrm{Zn}$ and Mn interfere with Fe utilization in the leaves for chlorophyll synthesis (Fageria, 2001).

\section{Zinc}

Leaf tissue $\mathrm{Zn}$ concentration for Gerbera plants treated with complete nutrient solution was recorded $57.53 \mathrm{ppm}$, whereas for plants treated with $\mathrm{Zn}$ deficient nutrient solution has recorded $12.4 \mathrm{ppm}$ (Table 2). For pot gerbera leaf tissue $\mathrm{Zn}$ concentration was reported to be 19-80 ppm (Dole and Wilkins, 2005) and in cut gerbera was 25-100 ppm, under $\mathrm{Zn}$ deficiency conditions, threshold level of $\mathrm{Zn}$ in cut Gerbera was reported to be $20 \mathrm{ppm}$
(Ocampo, 2001). There was significant reduction in the growth as compared to control treatment (Table 3). Decrease in values was recorded for plant height $(20.47 \mathrm{~cm}, 25.50$ $\mathrm{cm})$, leaf area $\left(36.39 \mathrm{~cm}^{2}, 44.34 \mathrm{~cm}^{2}\right)$, root length $(26.75 \mathrm{~cm}, 28.97 \mathrm{~cm})$ and shoot/root ratio $(2.45,2.88)$.

Phosphorous content in $\mathrm{Zn}$ deficient leaves was recorded more $(0.77 \%)$ (Table 2$)$ due to antagonisms between them as zinc deficiency enhanced the uptake rate of phosphorus by the roots and translocated to the shoots which can be part of an expression of higher passive permeability of the plasma membranes of root cells or impaired control of xylem loading (Storey, 2006).

\section{Copper}

Leaf tissue $\mathrm{Cu}$ concentration for Gerbera plants treated with complete nutrient solution was recorded $13.3 \mathrm{ppm}$, whereas for plants treated with $\mathrm{Fe}$ deficient nutrient solution has recorded $3.21 \mathrm{ppm}$ (Table 2). For pot gerbera leaf tissue $\mathrm{Cu}$ concentration was reported to be 2-10 ppm (Dole and Wilkins, 2005) and in cut gerbera was 6-20 ppm, under $\mathrm{Cu}$ deficiency conditions, threshold level of $\mathrm{Cu}$ in cut Gerbera was reported to be 4 ppm (Ocampo, 2001). There was significant reduction in the growth as compared to control treatment except for shoot/root ratio $(3.11,2.88)$ which recorded higher (Table 3 ). Decrease in values was recorded for plant height $(17.25 \mathrm{~cm}, 25.50$ $\mathrm{cm})$, leaf area $\left(35.65 \mathrm{~cm}^{2}, 44.34 \mathrm{~cm}^{2}\right)$ and root length $(23.59 \mathrm{~cm}, 28.97 \mathrm{~cm})$.

Iron content in $\mathrm{Cu}$ deficient leaves was recorded more (256.4 ppm) (Table 2) due to antagonism between them as $\mathrm{Cu}$ in excess interferes with plant's capacity to absorb and/or translocate other nutrients $(\mathrm{Fe})$ inhibiting root elongation and adversely affecting the permeability of the root cell membrane (Frageria, 2001). 
Table.1 Composition of nutrient solutions for various treatments $\left(\mathrm{ml} . \mathrm{l}^{-1}\right)$

\begin{tabular}{|c|c|}
\hline Treatment & Composition of nutrients (ml/lit) \\
\hline T1 (complete) & $\mathrm{KNO}_{3} @ 6 \mathrm{ml}+\mathrm{Ca}\left(\mathrm{NO}_{3}\right)_{2} \cdot 4 \mathrm{H}_{2} 0 @ 4 \mathrm{ml}+\mathrm{NH}_{4} \mathrm{H}_{2} \mathrm{PO}_{4} @ 2 \mathrm{ml}+\mathrm{MgSO}_{4} \cdot 7 \mathrm{H}_{2} 0 @ 1 \mathrm{ml}+\mathrm{Fe}-\mathrm{EDTA} @ 1 \mathrm{ml}+$ Micronutrients @ 1ml \\
\hline $\mathbf{T} 2(-\mathbf{N})$ & $\mathrm{MgSO}_{4} \cdot 7 \mathrm{H}_{2} \mathrm{0} @ 1 \mathrm{ml}+\mathrm{Fe}-\mathrm{EDTA} @ 1 \mathrm{ml}+$ Micronutrients@1ml + $\mathrm{CaCl}_{2} @ 4 \mathrm{ml}+\mathrm{KCl} @ 6 \mathrm{ml}+\mathrm{NaH}_{2} \mathrm{PO}_{4} \cdot 2 \mathrm{H}_{2} \mathrm{O} @ 2 \mathrm{ml}$ \\
\hline T3 (-P) & $\mathrm{KNO}_{3} @ 6 \mathrm{ml}+\mathrm{Ca}\left(\mathrm{NO}_{3}\right)_{2} \cdot 4 \mathrm{H}_{2} \mathrm{O} @ 4 \mathrm{ml}+\mathrm{MgSO}_{4} \cdot 7 \mathrm{H}_{2} 0 @ 1 \mathrm{ml}+\mathrm{Fe}-\mathrm{EDTA} @ 1 \mathrm{ml}+$ Micronutrients @ 1ml + $\mathrm{NH}_{4} \mathrm{Cl} @ 2 \mathrm{ml}$ \\
\hline T4 (-K) & $\mathrm{Ca}\left(\mathrm{NO}_{3}\right)_{2} \cdot 4 \mathrm{H}_{2} \mathrm{O} @ 4 \mathrm{ml}+\mathrm{NH}_{4} \mathrm{H}_{2} \mathrm{PO}_{4} @ 2 \mathrm{ml}+\mathrm{MgSO}_{4} \cdot 7 \mathrm{H}_{2} \mathrm{O} @ 1 \mathrm{ml}+\mathrm{Fe}$-EDTA @ 1ml + Micronutrients @ 1ml + $\mathrm{NaNO}_{3} @ 6 \mathrm{ml}$ \\
\hline T5 (-Ca) & $\mathrm{KNO}_{3} @ 6 \mathrm{ml}+\mathrm{NH}_{4} \mathrm{H}_{2} \mathrm{PO}_{4} @ 2 \mathrm{ml}+\mathrm{MgSO}_{4} \cdot 7 \mathrm{H}_{2} \mathrm{O} @ 1 \mathrm{ml}+\mathrm{Fe}$-EDTA @1ml + Micronutrients@1ml + $\mathrm{NaNO}_{3} @ 8 \mathrm{ml}$ \\
\hline T6 (-Mg) & $\mathrm{KNO}_{3} @ 6 \mathrm{ml}+\mathrm{Ca}\left(\mathrm{NO}_{3}\right)_{2} \cdot 4 \mathrm{H}_{2} \mathrm{O} @ 4 \mathrm{ml}+\mathrm{NH}_{4} \mathrm{H}_{2} \mathrm{PO}_{4} @ 2 \mathrm{ml}+\mathrm{Fe}$-EDTA @1ml + Micronutrients @ 1ml + $\mathrm{Na}_{2} \mathrm{SO}_{4} @ 1 \mathrm{ml}$ \\
\hline T7 (-S) & $\mathrm{KNO} 3 @ 6 \mathrm{ml}+\mathrm{Ca}\left(\mathrm{NO}_{3}\right)_{2} \cdot 4 \mathrm{H}_{2} \mathrm{O} @ 4 \mathrm{ml}+\mathrm{NH}_{4} \mathrm{H}_{2} \mathrm{PO}_{4} @ 2 \mathrm{ml}+\mathrm{Fe}$-EDTA @1ml + Micronutrients @ 1ml + $\mathrm{MgCl}_{2} \cdot 6 \mathrm{H}_{2} \mathrm{O} @ 1 \mathrm{ml}$ \\
\hline T8 (-Mn) & $\mathrm{KNO}_{3} @ 6 \mathrm{ml}+\mathrm{Ca}\left(\mathrm{NO}_{3}\right)_{2} \cdot 4 \mathrm{H}_{2} \mathrm{O} @ 4 \mathrm{ml}+\mathrm{NH}_{4} \mathrm{H}_{2} \mathrm{PO}_{4} @ 2 \mathrm{ml}+\mathrm{MgSO}_{4} \cdot 7 \mathrm{H}_{2} 0 @ 1 \mathrm{ml}+\mathrm{Fe}-\mathrm{EDTA} @ 1 \mathrm{ml}+$ Micronutrients @ 1ml-Mn \\
\hline T9 (-B) & $\mathrm{KNO}_{3} @ 6 \mathrm{ml}+\mathrm{Ca}\left(\mathrm{NO}_{3}\right)_{2} \cdot 4 \mathrm{H}_{2} \mathrm{O} @ 4 \mathrm{ml}+\mathrm{NH}_{4} \mathrm{H}_{2} \mathrm{PO}_{4} @ 2 \mathrm{ml}+\mathrm{MgSO}_{4} \cdot 7 \mathrm{H}_{2} \mathrm{O} @ 1 \mathrm{ml}+\mathrm{Fe}-\mathrm{EDTA} @ 1 \mathrm{ml}+$ Micronutrients @ 1ml- $\mathrm{B}$ \\
\hline T10 (-Fe) & $\mathrm{KNO}_{3} @ 6 \mathrm{ml}+\mathrm{Ca}\left(\mathrm{NO}_{3}\right)_{2} \cdot 4 \mathrm{H} 20 @ 4 \mathrm{ml}+\mathrm{NH}_{4} \mathrm{H}_{2} \mathrm{PO}_{4} @ 2 \mathrm{ml}+\mathrm{MgSO}_{4} .7 \mathrm{H}_{2} \mathrm{O} @ 1 \mathrm{ml}+$ Micronutrients @ 1ml \\
\hline T11 (-Zn) & $\mathrm{KNO}_{3} @ 6 \mathrm{ml}+\mathrm{Ca}\left(\mathrm{NO}_{3}\right)_{2} \cdot 4 \mathrm{H}_{2} \mathrm{O} @ 4 \mathrm{ml}+\mathrm{NH}_{4} \mathrm{H}_{2} \mathrm{PO}_{4} @ 2 \mathrm{ml}+\mathrm{MgSO}_{4} \cdot 7 \mathrm{H}_{2} \mathrm{O} @ 1 \mathrm{ml}+\mathrm{Fe}-\mathrm{EDTA} @ 1 \mathrm{ml}+$ Micronutrients @ 1ml-Zn \\
\hline T12 (-Cu) & $\mathrm{KNO}_{3} @ 6 \mathrm{ml}+\mathrm{Ca}\left(\mathrm{NO}_{3}\right)_{2} \cdot 4 \mathrm{H}_{2} \mathrm{O} @ 4 \mathrm{ml}+\mathrm{NH}_{4} \mathrm{H}_{2} \mathrm{PO}_{4} @ 2 \mathrm{ml}+\mathrm{MgSO}_{4} \cdot 7 \mathrm{H}_{2} 0 @ 1 \mathrm{ml}+\mathrm{Fe}-\mathrm{EDTA} @ 1 \mathrm{ml}+$ Micronutrients @1ml-Cu \\
\hline
\end{tabular}

Table.2 Leaf tissue concentrations of macro (\%) and micro nutrients (ppm) and their interaction levels in leaf tissues of cut Gerbera a var. Savannah

\begin{tabular}{|c|c|c|c|c|c|c|c|c|c|c|c|}
\hline \multicolumn{12}{|c|}{ Leaf tissue concentration of cut Gerbera var. Savannah. } \\
\hline Treatments & $\mathbf{N}$ & $\mathbf{P}$ & $\mathbf{K}$ & $\mathbf{C a}$ & Mg & $\mathbf{S}$ & Mn & B & $\mathbf{F e}$ & $\mathbf{Z n}$ & $\mathbf{C u}$ \\
\hline $\mathbf{T}_{1}($ Complete $)$ & 3.12 & 0.61 & 2.97 & 1.43 & 0.60 & 0.38 & 72.93 & 44.50 & 169.55 & 57.53 & 13.30 \\
\hline $\mathbf{T}_{2}(-\mathbf{N})$ & 1.10 & 0.47 & 3.20 & 1.84 & 0.58 & 0.67 & 55.67 & 59.25 & 205.5 & 73.35 & 11.35 \\
\hline $\mathrm{T}_{3}(-\mathrm{P})$ & 2.75 & 0.11 & 3.38 & 1.59 & 0.53 & 0.45 & 60.70 & 41.38 & 210.25 & 70.30 & 17.16 \\
\hline $\mathbf{T}_{4}(-\mathbf{K})$ & 3.45 & 0.65 & 1.46 & 1.78 & 0.79 & 0.38 & 94.63 & 60.50 & 45.00 & 63.80 & 18.70 \\
\hline$T_{5}(-\mathbf{C a})$ & 2.35 & 0.39 & 3.29 & 0.33 & 0.65 & 0.34 & 55.61 & 71.75 & 248.50 & 65.25 & 19.14 \\
\hline $\mathrm{T}_{6}(-\mathrm{Mg})$ & 2.68 & 0.71 & 3.51 & 2.09 & 0.13 & 0.49 & 109.45 & 22.80 & 121.40 & 71.55 & 12.15 \\
\hline $\mathbf{T}_{7}(-\mathbf{S})$ & 2.62 & 0.64 & 3.43 & 1.55 & 0.72 & 0.08 & 54.85 & 45.75 & 135.55 & 41.15 & 16.40 \\
\hline$T_{8}(-M n)$ & 2.63 & 0.31 & 3.44 & 1.44 & 0.63 & 0.42 & 28.40 & 33.85 & 225.20 & 53.50 & 19.40 \\
\hline$T_{9}(-B)$ & 2.60 & 0.41 & 2.67 & 1.95 & 0.60 & 0.43 & 55.03 & 14.60 & 159.80 & 68.05 & 18.10 \\
\hline $\mathrm{T}_{10}(-\mathrm{Fe})$ & 2.56 & 0.35 & 2.71 & 1.15 & 0.63 & 0.41 & 51.24 & 68.50 & 36.58 & 79.25 & 28.50 \\
\hline$T_{11}(-Z n)$ & 2.75 & 0.77 & 3.05 & 1.5 & 0.51 & 0.55 & 55.52 & 36.35 & 197.50 & 12.40 & 25.20 \\
\hline $\mathbf{T}_{12}(-\mathrm{Cu})$ & 2.60 & 0.70 & 3.22 & 1.16 & 0.65 & 0.525 & 52.05 & 46.61 & 256.40 & 67.15 & 3.21 \\
\hline S Em \pm & 0.032 & 0.008 & 0.008 & 0.009 & 0.009 & 0.004 & 0.284 & 0.289 & 0.446 & 0.224 & 0.206 \\
\hline C D $(p=0.05)$ & 0.099 & 0.025 & 0.026 & 0.028 & 0.029 & 0.011 & 0.885 & 0.901 & 1.39 & 0.699 & 0.641 \\
\hline
\end{tabular}


Table.3 Effect of different nutrient deficiencies on growth parameters of Gerbera at 60 DAT

\begin{tabular}{|c|c|c|c|c|}
\hline Treatments & $\begin{array}{l}\text { Plant } \\
\text { height } \\
\text { (cm) }\end{array}$ & $\begin{array}{l}\text { Leaf area } \\
\quad\left(\mathrm{cm}^{2}\right)\end{array}$ & $\begin{array}{l}\text { Root length } \\
\text { (cm) }\end{array}$ & $\begin{array}{c}\text { Shoot/Root } \\
\text { ratio }\end{array}$ \\
\hline $\mathbf{T}_{1}($ Complete $)$ & 25.50 & 44.34 & 28.97 & 2.88 \\
\hline $\mathbf{T}_{2}(-\mathbf{N})$ & 11.40 & 20.87 & 13.65 & 2.12 \\
\hline$T_{3}(-P)$ & 14.50 & 22.23 & 33.20 & 3.12 \\
\hline $\mathbf{T}_{4}(-\mathbf{K})$ & 16.40 & 28.45 & 22.84 & 3.45 \\
\hline $\mathrm{T}_{5}(-\mathrm{Ca})$ & 15.63 & 25.55 & 19.38 & 2.75 \\
\hline $\mathrm{T}_{6}(-\mathrm{Mg})$ & 17.87 & 31.78 & 19.75 & 3.26 \\
\hline $\mathbf{T}_{7}(-\mathbf{S})$ & 18.77 & 32.38 & 19.58 & 2.98 \\
\hline $\mathbf{T}_{8}(-\mathbf{M n})$ & 22.15 & 37.78 & 26.41 & 2.66 \\
\hline $\mathrm{T}_{9}(-\mathrm{B})$ & 21.55 & 34.57 & 22.43 & 2.86 \\
\hline $\mathbf{T}_{10}(-\mathrm{Fe})$ & 13.41 & 33.60 & 16.40 & 3.39 \\
\hline$T_{11}(-Z n)$ & 20.47 & 36.39 & 26.75 & 2.45 \\
\hline $\mathbf{T}_{12}(-\mathrm{Cu})$ & 17.25 & 35.65 & 23.59 & 3.11 \\
\hline $\mathrm{SEm} \pm$ & 0.142 & 0.126 & 0.172 & 0.09 \\
\hline C D $(p=0.05)$ & 0.416 & 0.369 & 0.504 & 0.265 \\
\hline
\end{tabular}

Fig.1 Gerbera plants grown in complete and deficiency nutrient solutions

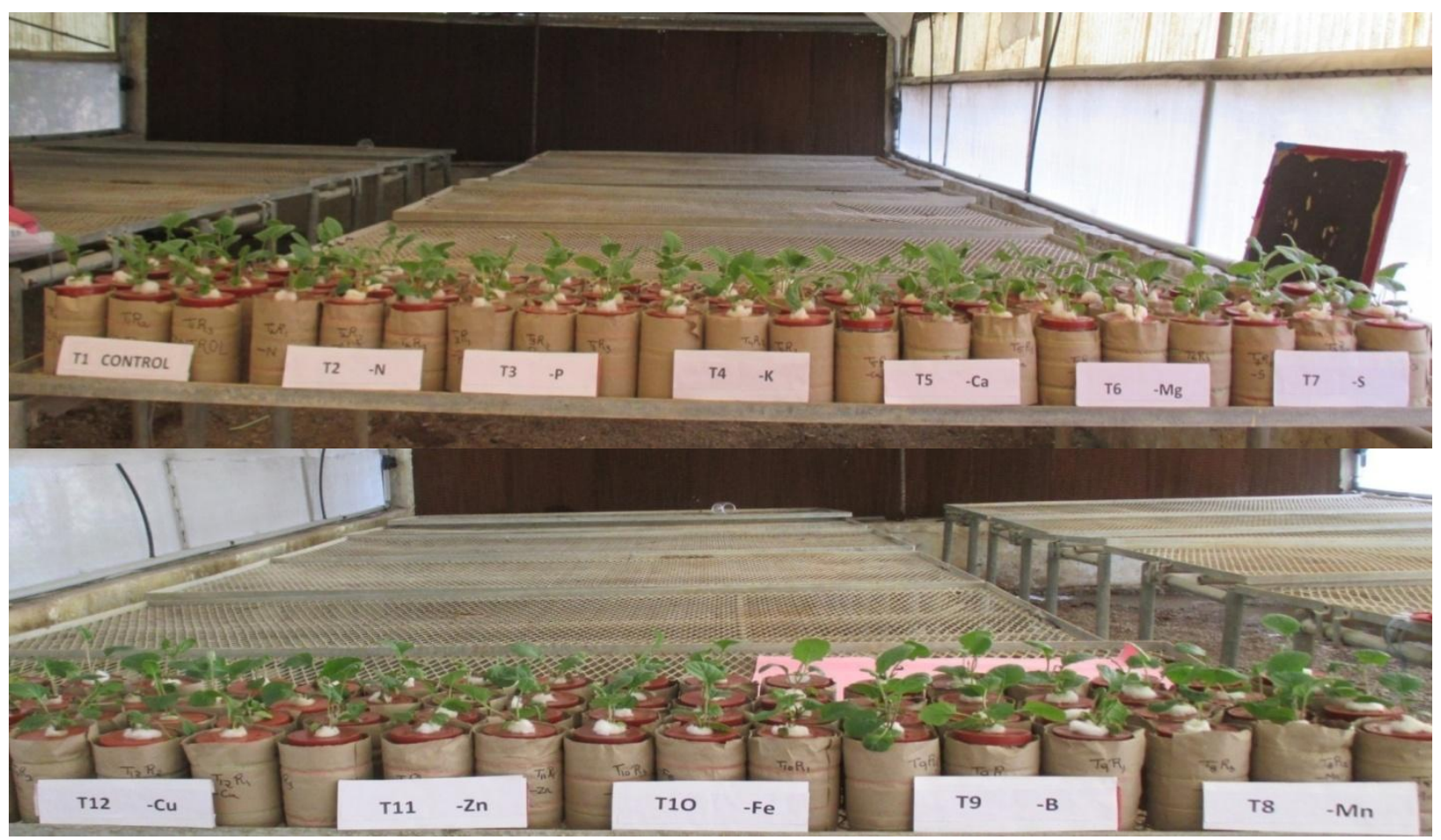


Fig.2 Gerbera plants aerated with aspirator

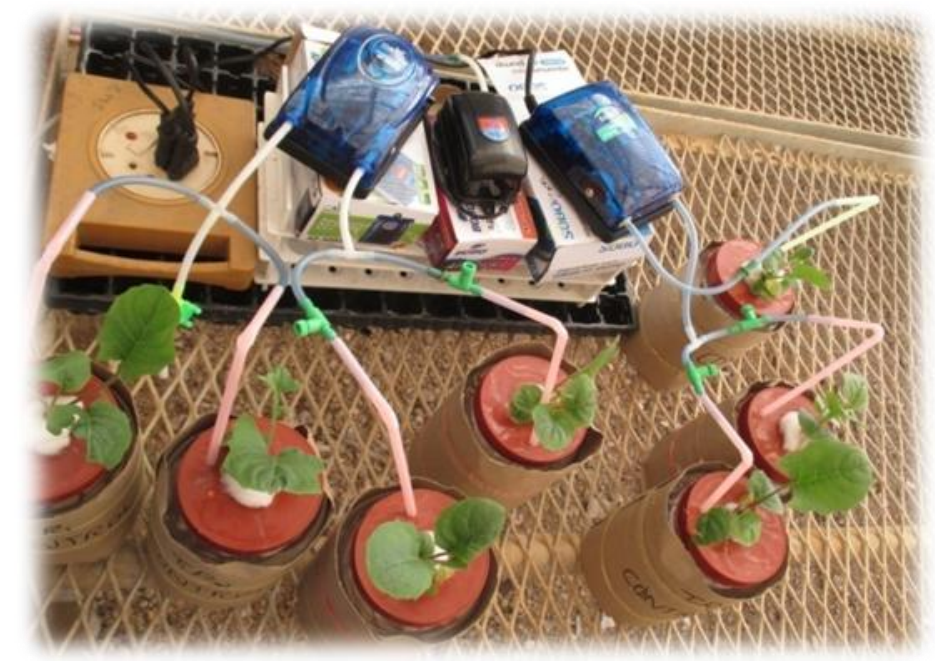

It can be concluded that, plants grown in complete nutrient solution recorded maximum growth compared to individual deficiency treatments. Under deficiency conditions, content of individual mineral element has been reduced. Deficiency of $\mathrm{N}$ had reduced plant growth significantly followed by $\mathrm{P}, \mathrm{K}$, $\mathrm{Ca}, \mathrm{Fe}$ and $\mathrm{Mg}$. Whereas, remaining elements affected plant growth marginally.

\section{References}

Anonymous.2014-15. National Horticulture Data Base National Horticulture Board. Ministry of Agriculture, Government of India.

Berger, K.C. and Trough, E. 1939. Boron determination in soils and plants. Ind. Eng. Chem. Anal. Ed.11:540-545.

Chang, D.C. Kim, S.Y. Jeong, J.C and Shin, K.Y. 2001. Effects of potassium and Calcium concentration in nutrient solution on the growth and mineral uptake by Potatoes. International Society of Horticultural Science, Acta Hort. 548: 477-483.

Chesnin, L and Yien, C.H.1950. Turbedimetric determination of available sulphates. Proc. Soil Sci. Soc. Am. 14:149-151.

Cohu, C.M. and Pilon, M. 2007. Regulation of superoxide dismutase expression by copper availability. Physiologia Plantarum. 129(4): 747-755

Dole, J.M. and Wilkins, H.F. 2005. Floriculture Principles and Species, 2 ed., Pearson-Prentice Hall, Upper Saddle River, New Jersey.

Frageria, V.D. 2001. Nutrient interactions in crop plants. Journal of Plant Nutrition. 24(8): 1269-1290.

Fredeen, A.L. Rao, I.M and Terry, N. 1989. Influence of phosphorous nutrition on growth and carbon partitioning in Glycine max. Plant physiology. 89: 225-230.

Gama, F. Saavedra, T. Diaz, T.I. Campillo, M.D.C. Varennes, A.D and Duarte, A. 2015. Fe deficiency induction in Poncirus trifoliata rootstock growing in nutrient solution changes its performance after transplant to soil. Scientia Horticultura. 182: 102-109.

Hoagland, R.J and Arnon, D.I. 1950. The Water-Culture Method for Growing Plants without Soil, Circ. 347 (Rev. 
edition). California Agricultural Experimental Station, Berkeley, California.

Jackson, M.L.1973. Soil Chemical Analysis, Prentice-Hall of India Pvt. Ltd., New Delhi.

Merhaut, D.J.2006. Magnesium in A.V. Barker and D.J Pilbeam (eds) Hand book of Plant Nutrition, CRC press, eBook.146-165.

Ocampo, M. V. 2001. Gerbera. Ediciones Hortitecnia Ltda., Bogotá, Colombia.

Storey, J.B.2006. Zinc in A.V. Barker and D.J Pilbeam (eds) Hand book of Plant Nutrition, CRC press, eBook. 411-430

Subbaiah, B.V. and Asija, G.L. 1956. A rapid procedure for the determination of available nitrogen in soils. Current Science 25: 259-260.

Sujatha K, Gowda J V N and Khan M M. 2002. Effects of different fertigation levels on gerbera under low cost greenhouse. J. Orn. Hort. New Series. 5(1): 54-59.

Tandon, H.L.S. 1993. Methods of Analysis of soils, plants, water and fertilizers (ed.). Fertilizer Development and Consultation Organization, New Delhi.

Turan, M. Nizamettin, A. Adem, G and Taskin, O.2009. Yield and Chemical Composition of Brussels Sprout (Brassica oleracea L. gemmifera) as Affected by Boron Management. HortScience. 44(1): 176-182.

Ujwala, R.M. 2011. Interaction of micronutrients with major nutrients with special reference to potassium. Karnataka J. Agric. Sci. 24(1): 106109.

\section{How to cite this article:}

Sai Ratna Sharavani, Ch., Neeraja Prabhakar, B., Chandini Patnaik, M. and Girwani, A. 2018. Effect of Nutrient Deficiencies on Growth and Leaf Tissue Concentration of Gerbera var. Savannah. Int.J.Curr.Microbiol.App.Sci. 7(08): 2615-2623.

doi: https://doi.org/10.20546/ijcmas.2018.708.269 